\author{
Katarzyna CHUDY ${ }^{1}$ \\ Marek SOBOLEWSKI ${ }^{2}$ \\ Kinga STĘPIEN ${ }^{3}$
}

\title{
OCENA PRODUKTYWNOŚCI BANKÓW W POLSCE Z ZASTOSOWANIEM METOD TAKSONOMII ${ }^{4}$
}

Głównym celem artykułu jest ocena całkowitej produktywności banków w Polsce. W badaniach wykorzystano metodę DEA, indeks Malmquista, taksonomiczną metodę Warda oraz metodę średnich grupowych. Analiza pozwoliła na wyodrębnienie skupień banków o podobnym poziomie produktywności w wybranych momentach czasowych.

Slowa kluczowe: produktywność, DEA, banki w Polsce.

\section{WPROWADZENIE}

Celem artykułu jest ocena zmian całkowitej produktywności banków komercyjnych w Polsce. Na podstawie wskaźników zmiany produktywności przeprowadzono analizę taksonomiczną, w wyniku której zidentyfikowano klastry bankowe. Dzięki temu wskazano banki o podobnym poziomie produktywności. Podstawowymi narzędziami badawczymi są nieparametryczna metoda Data Envelopment Analysis (DEA) ${ }^{5}$ oraz indeks Malmquista 6. Następnie wykorzystano procedurę taksonomiczną umożliwiającą przeprowadzenie grupowania banków ze względu na wybrane zmienne.

Schemat analizy zastosowany w niniejszym opracowaniu może poszerzyć metodykę analiz porównawczych sprawności banków w Polsce, która w pewnym stopniu ogranicza się do wykorzystania wskaźników analizy finansowej, wskaźników giełdowych lub narzędzi przeznaczonych dla inwestorów giełdowych. Interpretacja średnich grupowych indeksu Malmquista oraz jego elementów składowych pozwala na sformułowanie wniosków uwzględniających rzeczywistą relację wyników produkcji i zaangażowanych w tym procesie nakładów oraz zmian całkowitej produktywności w podziale na grupy banków. Narzędzia z zakresu taksonomii pozwalają na przeprowadzenie analizy porównawczej poszczególnych skupień banków oraz przebiegu zmienności wybranych cech w czasie.

\footnotetext{
${ }^{1}$ Dr Katarzyna Chudy, Katedra Metod Ilościowych, Politechnika Rzeszowska.

${ }^{2}$ Dr Marek Sobolewski, Katedra Metod Ilościowych, Politechnika Rzeszowska.

${ }^{3}$ Dr Kinga Stepień, Katedra Metod Ilościowych, Politechnika Rzeszowska.

${ }^{4}$ Praca naukowa finansowana ze środków na naukę w latach 2007-2009 w ramach projektu badawczego „Kompleksowa analiza produktywności banków w Polsce - wyodrębnienie klastrów bankowych” (2602/B/H03/2007/33).

${ }^{5}$ Data Envelopment Analysis jest nieparametryczną metodą do badania względnej efektywności przedsiębiorstw w warunkach wystepowania wiecej niż jednego nakładu oraz wieccej niż jednego efektu. Metoda DEA została opracowana w 1978 r. przez Abrahama Charnesa, Williama W. Coopera oraz Edwarda Rhodesa. Zobacz A. Charnes, W.W. Cooper, E. Rhodes, Measuring the efficiency of decision making units, „European Journal of Operational Reasearch" 1978/2, s. 429-444.

${ }^{6}$ Idea wskaźnika Malmquista opiera się na indeksie produktywności, rozumianym jako stosunek poziomu produktywności danej jednostki w czasie t oraz $\mathrm{t}+1$.
} 


\section{METODYKA BADANIA}

W niniejszym artykule wykorzystuje się nieparametryczną metodę $\mathrm{DEA}^{7}$ użytą do oszacowania miar efektywności banków komercyjnych, indeks Malmquista do pomiaru zmian produktywności w latach 1996-1997, 2001-2002 oraz 2006-2007, metodę Warda do analizy klastrów bankowych oraz metodę średnich grupowych.

$\mathrm{W}$ analizie z zastosowaniem metody DEA konieczny jest wybór właściwych nakładów i efektów, które w uproszczony modelowy sposób oddają charakter funkcjonowania banku. Przegląd istniejących koncepcji przedstawiono w trzeciej części artykułu. Oszacowanie efektywności banków metodą DEA wymaga w odniesieniu do każdego banku wyliczenia całkowitej efektywności technicznej (TE, technical efficiency), wyliczenia czystej efektywności technicznej banku (PTE, pure technical efficiency), wyliczenia efektywności skali banku jako ilorazu TE i PTE oraz określenia rodzajów efektów skali banku.

Ponieważ w wyniku analiz prowadzonych za pomocą metody DEA otrzymuje się względne miary efektywności, wskazana jest dalsza analiza z uwzględnieniem otrzymanych współczynników efektywności. Pomiar zmian efektywności w czasie jest możliwy za pomoca indeksu produktywności Malmquista. W wyniku tego pomiaru uzyskuje się współczynnik zmiany produktywności banku. Dla wartości indeksu większej niż 1 przyjmuje się, że w badanym okresie (od t do $\mathrm{t}+1$ ) nastapił relatywny wzrost produktywności, natomiast jeśli wartość indeksu jest mniejsza niż 1, to wskazuje to na spadek produktywności, równa zaś 1 na utrzymanie się jej na poziomie niezmienionym.

W indeksie Malmquista po dokonaniu niezbędnych modyfikacji można wyróżnić elementy składowe: wskaźnik postępu technicznego (technical change) - względne przesunięcie granicy możliwości produkcyjnych badanego podmiotu - oraz wskaźnik efektywności technicznej (efficiency change) - liniowy odstęp jednostki decyzyjnej od granicy produkcji.

Kolejnym etapem analizy jest grupowanie banków ze względu na przyjęte zmienne diagnostyczne za pomocą metody taksonomicznej. Wyniki badań przedstawiono przy użyciu metody Joe H. Warda ${ }^{8}$. Na podstawie analizy wariancji, opracował on metodę hierarchicznej analizy aglomeracyjnej, która zapewnia podział dający minimalną wariancję wewnątrz uzyskiwanych skupień, maksymalną wariancję zaś pomiędzy skupieniami. W metodzie Warda odległość skupisk wyrażona jest różnicą między sumami kwadratów odchyleń odległości poszczególnych jednostek środka ciężkości grup, do których punkty te należą.

\section{PRZEGLAD WYBRANYCH KONCEPCJI DOBORU NAKLADÓW I EFEKTÓW W DZIALALNOŚCI BANKU}

W literaturze przedmiotu zasadniczo wymienia się następujące podejścia dotyczące modelowania zachowań banku oraz określania wyników jego działalności: produkcyjne (production approach), pośrednika (intermediation approach), zasobów finansowych (assets approach), wartości dodanej (value added approach) oraz kosztu użytkownika (cost user approach $)^{9}$.

\footnotetext{
${ }^{7}$ Teoretyczne aspekty metody DEA opisano w literaturze. Zob. więcej M. Gospodarowicz, Procedury analizy $i$ oceny banków, „Materiały i Studia”, NBP, Warszawa 2005/103.

${ }^{8}$ J.H. Ward, Hierarchical Grouping to Optimize an Objective Function, ,Journal of the American Statistical Association" 1963/58, s. 236-244.

${ }^{9}$ D.C. Wheelock, P.W. Wilson, Evaluating the efficiency of commercial banks: does our view of what banks do matter?, „Review of Federal Reserve Bank of St. Louis” 1995/77, s. 40-42.
} 
Koncepcje producenta i pośrednika wywodzą się $\mathrm{z}$ mikroekonomicznej teorii przedsiębiorstwa odniesionej do sektora bankowego. Różnice między nimi sprowadzają się do sposobu specyfikacji czynności bankowych ${ }^{10}$. W wypadku koncepcji producenta głównym celem funkcjonowania banku jest produkcja usług bankowych (wkłady i kredyty). Dlatego też nakładami są wydatki nieodsetkowe, to znaczy koszty osobowe, materiałowe, koszty amortyzacji budynków i gruntów, efektem działalności natomiast jest liczba prowadzonych rachunków (wkłady terminowe, oszczędnościowe, rachunki bieżące, kredyty hipoteczne, konsumenckie) ${ }^{11}$. Koncepcja ta jest przydatna podczas badania wydajności banku w wypełnianiu jego zadań związanych z prowadzeniem kont.

W podejściu pośrednika akcentuje się aktywność banku polegającą na przyjmowaniu wkładów klientów oraz dostarczaniu kredytów i innych środków inwestycyjnych. Po stronie efektów można zaklasyfikować pieniężną wartość udzielonych kredytów oraz środków na inwestycje. Natomiast po stronie nakładów koszty odsetkowe, materiałowe oraz osobowe. Depozyty traktowane są jako nakłady banku. W obu modelach umieszcza się kredyty i inne aktywa po stronie efektów. Brak natomiast jednoznacznego ustalenia miejsca depozytów, które są traktowane bądź jako nakłady, bądź jako efekty działalności bankowej. Oba te rozwiązania mają uzasadnienie teoretyczne ${ }^{12}$. Podobnie nie ma jednoznacznych rozstrzygnięć co do istotnych różnic w poziomie efektywności w zależności od umiejscowienia depozytów. Istniejące $\mathrm{w}$ tej kwestii kontrowersje odzwierciedla bogate piśmiennictwo naukowe, na którego łamach badacze zjawiska starali się ocenić przydatność poszczególnych podejść do badania efektywności banków ${ }^{13}$.

Koncepcja zasobów finansowych opiera się na założeniu, że bank dostarcza usług kredytowych oraz środków na inwestycje z przyjmowanych depozytów, angażując także kapitał ludzki i majątek trwały. Krytyka tej koncepcji dotyczy pomijania w niej faktu, że bank zużywa także zasoby będące $\mathrm{w}$ jego dyspozycji podczas realizacji transakcji rozliczeniowych $\mathrm{i}$ obsługi depozytów oszczędnościowych ${ }^{14}$.

W koncepcji wartości dodanej zakłada się, że efektem działania banku jest każdy rodzaj aktywności, w której zużywają się jego zasoby. W podejściu kosztu użytkownika koszt składników aktywów jest kalkulowany jako różnica między kosztem alternatywnym kapitału banku i zwrotem z niego. Koszt składników pasywów jest wyznaczany jako różnica pomiędzy kosztem ich uzyskania a kosztem alternatywnym kapitału. Wybrane składniki aktywów i pasywów mogą być klasyfikowane zarówno jako nakłady, jak i efekty w działalności banku w zależności od związanego z nimi kosztu użytkownika.

\section{OGÓLNE UWAGI DOTYCZACCE PROCESU BADAWCZEGO}

Analizą objęto 27 banków komercyjnych w trzech momentach czasowych: w okresie 1996-1997, 2001-2002 oraz 2006-2007. Dobór banków do analizowanej próby był

\footnotetext{
${ }^{10}$ X. Freixas, J.Ch. Rochet, Mikroekonomia bankowa, CeDeWu, Warszawa 2007, s. 117.

${ }^{11}$ M. Gospodarowicz, Procedury analizy i oceny banków, „Materiały i Studia”, NBP, Warszawa 2005/103, s. 16.

12 A.N. Berger, D.N. Humprey, Efficiency of Financial Institutions: International Survey and Directions for Future Research, [w:] Performance of Financial Institution, [red. P. Harker, S. Zenios, Cambridge University Press, New York 1999], Oxford University Press, Oxford 1999.

${ }^{13}$ C.A. Favero, L. Papi, Technical Efficiency and Scale Efficiency in the Italian Banking Sector: Non-parametric Approach, „Applied Economics” 1995/27, s. 386-395; A. Berger, D.B. Humprey, Measurement and Efficiency Issue in Commercial Banking, [w:] Output Measurement in the Service Sector, red. Z. Griliches, The University of Chicago Press, Chicago 1992, s. 245-279.

${ }^{14}$ Zob. więcej A. Berger, D.B. Humprey, Measurement and Efficiency..., s. 245-279.
} 
uwarunkowany dostępnością danych o wielkości nakładów i efektów w czasie objętym badaniem. Dane te pochodzą z jednostkowych sprawozdań finansowych lub z rankingu „50 największych banków w Polsce” publikowanego corocznie na łamach MF „Bank”.

Pod względem wielkości sumy bilansowej na koniec 2007 r. analizowana grupa banków charakteryzowała się dużą różnorodnością (tab. 1) ${ }^{15}$. W odniesieniu do profilu prowadzonej działalności analizowane banki można podzielić na uniwersalne, detaliczne oraz korporacyjne. Ponad połowę banków przyjętych do badania można określić jako banki uniwersalne w zakresie oferty produktów podstawowych, realizujące jednocześnie strategie selektywne ukierunkowane na obsługę określonych segmentów klientów ${ }^{16}$. Wśród banków określanych jako detaliczne znalazły się zarówno te, które skupiają się na obsłudze segmentu najzamożniejszych klientów, jak i te, które koncentrują się na segmencie niezamożnych klientów oraz oferują wysoko rentowne produkty kredytowe, w tym kredyt hipoteczny oraz usługi finansujące zakup samochodów ${ }^{17}$. Do grupy banków korporacyjnych zaliczono banki mniejszych rozmiarów, które niemal wyłącznie obsługują podmioty gospodarcze lub ich wybrane segmenty i które mają wysoko specjalistyczną ofertę produktową skierowaną tylko do tego typu klientów ${ }^{18}$. Największe banki, które zajmują dominujące pozycje także w segmencie podmiotów gospodarczych, uznano na potrzeby niniejszego opracowania za banki o uniwersalnym charakterze ze względu na to, że realizują strategię banku uniwersalnego z ukierunkowaniem na wybrane segmenty produktów finansowych. W badanej populacji banków nie uwzględniono banków internetowych oraz hipotecznych.

Tabela 1. Podział analizowanych banków według wielkości aktywów na koniec 2007 r.

\begin{tabular}{|c|l|}
\hline $\begin{array}{c}\text { Aktywa na } \\
\text { koniec 2007 r. } \\
\text { w mld zl }\end{array}$ & \multicolumn{1}{c|}{ Banki } \\
\hline$>100$ & PEKAO, PKO BP \\
\hline $75-100$ & \\
\hline $50-75$ & BRE, ING Bank Śląski \\
\hline $25-50$ & Bank Zachodni WBK, Bank Handlowy, Bank Millennium, Kredyt Bank \\
\hline$<25$ & $\begin{array}{l}\text { Bank BGŻ, Raiffeisen, Getin Bank, GE Money Bank, Fortis Bank, Bank } \\
\text { BPH, Nordea, BOŚ, Lukas Bank (Credit Agricole), Rabobank, Deutsche } \\
\text { Bank Polska, DnB Nord Polska, AIG Bank Polska, Bank Pocztowy, West } \\
\text { LB, Invest Bank, DZ Bank, ABN Amro, Dominet Bank }\end{array}$ \\
\hline
\end{tabular}

Dane statystyczne po stronie nakładów i efektów wyselekcjonowano na podstawie koncepcji pośrednika. Za nakłady przyjęto majątek trwały, zobowiązania całkowite oraz koszty działania banku. Do efektów zaliczono należności całkowite, portfel papierów wartościowych oraz wynik z tytułu prowizji. Do oszacowania miar efektywności zastosowano model uwzględniający efekty skali zorientowany na nakłady. Następnie przeprowadzono pomiar względnej zmiany efektywności oraz postępu technologicznego między okresem $t \mathrm{i}$

\footnotetext{
${ }^{15}$ Umowną klasyfikację według profilu prowadzonej działalności przeprowadzono w grupie badanych banków na podstawie szczegółowych rankingów banków za 2007 r. prezentowanych w ramach Rankingu 50 największych banków w Polsce.

${ }^{16}$ PEKAO, PKO BP, BRE, Millennium, BZ WBK, ING BŚ, BGŻ, Kredyt Bank, Bank Handlowy, BOŚ, BPH, DnB Nord, Fortis Bank, Nordea Bank, Raiffeisen.

${ }^{17}$ Getin Bank, Lukas Bank, AIG Bank, GE Money Bank, Invest-Bank, Dominet Bank.

${ }^{18}$ DZ Bank, Deutsche Bank Polska, ABN Amro, West LB, Rabobank.
} 
$t+1^{19}$. Otrzymane $\mathrm{w}$ ten sposób wskaźniki charakteryzujące całkowitą produktywność poszczególnych banków wprowadzono do analizy grupowania, w której wykorzystano metodę Warda. Do identyfikacji poziomu cech diagnostycznych w poszczególnych skupieniach użyto metody średnich grupowych. Pozwala ona na wskazanie tych wskaźników, które zadecydowały o powstaniu danego klastra, oraz na określenie ich poziomu.

\section{SZCZEGÓLOWE WYNIKI ANALIZ EMPIRYCZNYCH}

W okresie 1996-1997 r. pod względem zmian poziomu produktywności całkowitej wyodrębniono cztery klastry banków. Najliczniejsza pod względem liczby banków jest grupa A (16 banków), do której zaklasyfikowano duże banki uniwersalne, mniejszych rozmiarów banki detaliczne oraz bank korporacyjny (rys. 1). Mimo zróżnicowania w wielkości i profilu działalności banki, które utworzyły ten klaster, wykazywały w latach 1996-1997 podobieństwa w zmianie poziomu produktywności całkowitej mierzonej indeksem Malmquista oraz kształtowania się jego elementów składowych. Średni poziom zmiany produktywności całkowitej w tej grupie wynosił 0,942 . Minimalny i maksymalny poziom indeksu Malmquista świadczy o istnieniu znacznej rozpiętości pomiędzy zmianami produktywności banków, które utworzyły to skupienie (tab. 2).

Charakterystyczna cecha banków grupy A polegała na tym, że w latach 1996-1997 nastapiły niewielka korzystna zmiana w zakresie poprawy wykorzystania nakładów oraz regres w zakresie zmiany technologii. Poprawa pod względem efektywności technicznej nie zrekompensowała jednak negatywnych tendencji dotyczących możliwości produkcyjnych. Analizowane banki wykazywały średnio spadek produktywności całkowitej.

Rys. 1. Klastry bankowe w latach 1996-1997

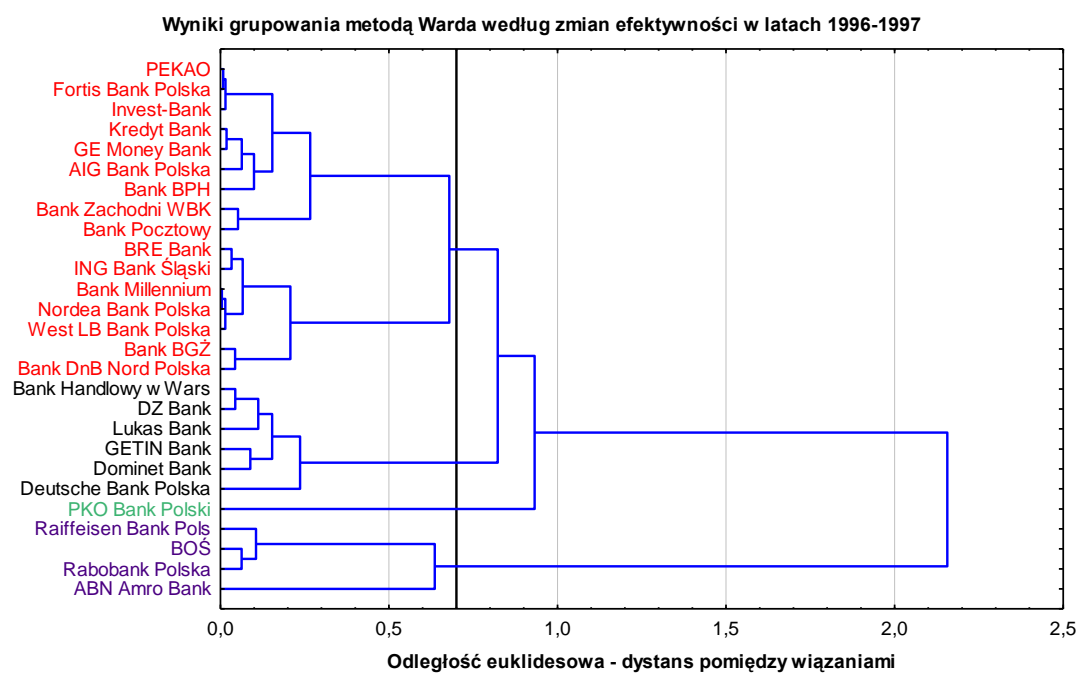

Źródło: opracowanie własne.

Do grupy B zaklasyfikowano sześć banków (rys. 1, tab. 2). Także w tym wypadku są to jednostki o różnorodnych rozmiarach i profilach działalności. W okresie 1996-1997 r. W

\footnotetext{
${ }^{19}$ Do obliczeń zastosowano program opracowany przez prof. Tima Coelli, A Data Envelopment Analysis (Computer) Program, DEAP Version 2.1 .
} 
bankach tych nastąpił spadek średniej produktywności o około 6\%. Było to spowodowane nieefektywnym pośrednictwem pomiędzy podmiotami nadwyżkowymi i deficytowymi. W 1997 r. w porównaniu z poprzednim okresem średnia efektywność techniczna banków z tej grupy obniżyła się o ponad $10 \%$. Mimo to nastapiła korzystna zmiana technologii, która jednak nie zniwelowała pogorszenia się w wykorzystaniu posiadanych zasobów.

Grupa C jest skupieniem jednoelementowym, które utworzył bank PKO BP. Charakterystyczna dla tego banku była znacząca poprawa efektywności technicznej (około $46 \%$ ) oraz regres pod względem postępu technologicznego (około 31\%). Produktywność całkowita PKO BP nieznacznie wzrosła.

Tabela 2. Wybrane statystyki opisowe wskaźników w powstałych klastrach bankowych w latach 1996-1997

\begin{tabular}{|c|c|c|c|c|c|c|c|c|c|}
\hline \multirow{2}{*}{ Grupa } & \multicolumn{3}{|c|}{ EFF CH } & \multicolumn{3}{c|}{ TECH CH } & \multicolumn{3}{c|}{ TFP CH } \\
\cline { 2 - 10 } & średnia & min. & maks. & średnia & min. & maks. & średnia & min. & maks. \\
\hline A & 1,015 & 0,963 & 1,106 & 0,928 & 0,835 & 1,038 & 0,942 & 0,820 & 1,045 \\
\hline B & 0,893 & 0,838 & 0,925 & 1,045 & 0,971 & 1,141 & 0,933 & 0,844 & 1,043 \\
\hline C & 1,459 & 1,459 & 1,459 & 0,687 & 0,687 & 0,687 & 1,003 & 1,003 & 1,003 \\
\hline D & 1,008 & 1,000 & 1,030 & 1,286 & 1,172 & 1,530 & 1,295 & 1,172 & 1,530 \\
\hline Ogół & 1,003 & 0,838 & 1,459 & 0,998 & 0,687 & 1,530 & 0,994 & 0,820 & 1,530 \\
\hline
\end{tabular}

EFF CH - zmiana efektywności, TECH CH - zmiana poziomu możliwości technologicznych, TFP CH - całkowita zmiana produktywności

Źródło: opracowanie własne.

Do grupy D zakwalifikowano cztery banki. Dwa z nich są bankami korporacyjnymi, BOŚ i Raiffeisen zaliczono do banków uniwersalnych. W wypadku tej grupy nastąpił niewielki spadek całkowitej produktywności, który spowodował regres elementu odzwierciedlającego postęp technologiczny. Występowały duże rozpiętości między maksymalnym a minimalnym poziomem indeksu Malmquista oraz jego składowych.

Rys. 2. Graficzna prezentacja poziomu wskaźników w powstałych klastrach bankowych w latach1996-1997

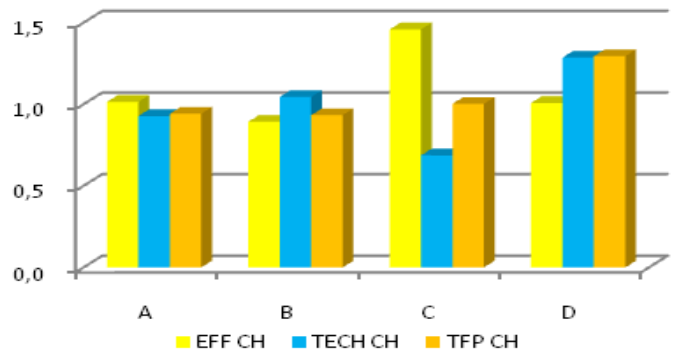

EFF CH - zmiana efektywności, TECH CH - zmiana poziomu możliwości technologicznych,

TFP CH - całkowita zmiana produktywności

Źródło: opracowanie własne.

Na rysunku 2 przedstawiono graficzną prezentację poziomu omawianych wskaźników w poszczególnych klastrach bankowych w latach 1996-1997 z dwóch perspektyw. W 
pierwszym przypadku porównuje się poziom każdego wskaźnika osobno w czterech wyodrębnionych grupach. W drugim przypadku zastosowano ujęcie prezentowania średniego poziomu trzech analizowanych wskaźników w każdej z grup z osobna.

Największą zmianę efektywności technicznej obserwowano $\mathrm{w}$ grupie $\mathrm{C}$, najniższą $\mathrm{w}$ grupie B. Pod względem zmiany technologii najwyższy poziom wykazywały banki z grupy D, najniższy natomiast $\mathrm{z}$ grupy $\mathrm{C}$. Wzrost produktywności całkowitej nastapił $\mathrm{w}$ grupie D. Niewielką korzystną zmianę odnotowały także banki z grupy C.

W latach 2001-2002 analizowana populacja 27 banków podzieliła się na pięć klastrów pod względem zmian w poziomie produktywności całkowitej. Skład klastrów, podstawowe statystyki opisowe oraz graficzną prezentację poziomu wskaźników w powstałych klastrach przedstawiono odpowiednio na rysunku 3, w tabeli 3 i na rysunku 4.

W skład grupy A weszło osiem banków. Są to banki uniwersalne i detaliczne. Charakterystyczny dla tej grupy jest niewielki średni wzrost produktywności całkowitej (TFP $\mathrm{CH} 2,3 \%$ ), przy postępie technologicznym (TECH CH 2,9\%) i obniżeniu się średniej efektywności technicznej (EFF CH 0,6\%).

Grupę B tworzy siedem banków, które zanotowały średni wzrost produktywności o 22,6\%. Banki te odnotowały niewielkie pogorszenie się średniego poziomu efektywności technicznej i jednoczesny wzrost możliwości produkcyjnych na skutek postępu technologicznego (TECH $\mathrm{CH} 24,5 \%$ ). Charakterystyczne jest, że wszystkie banki z tej grupy zanotowały wzrost poziomu wskaźnika produktywności całkowitej i wskaźnika postępu technicznego.

Rys. 3. Klastry bankowe w latach 2001-2002

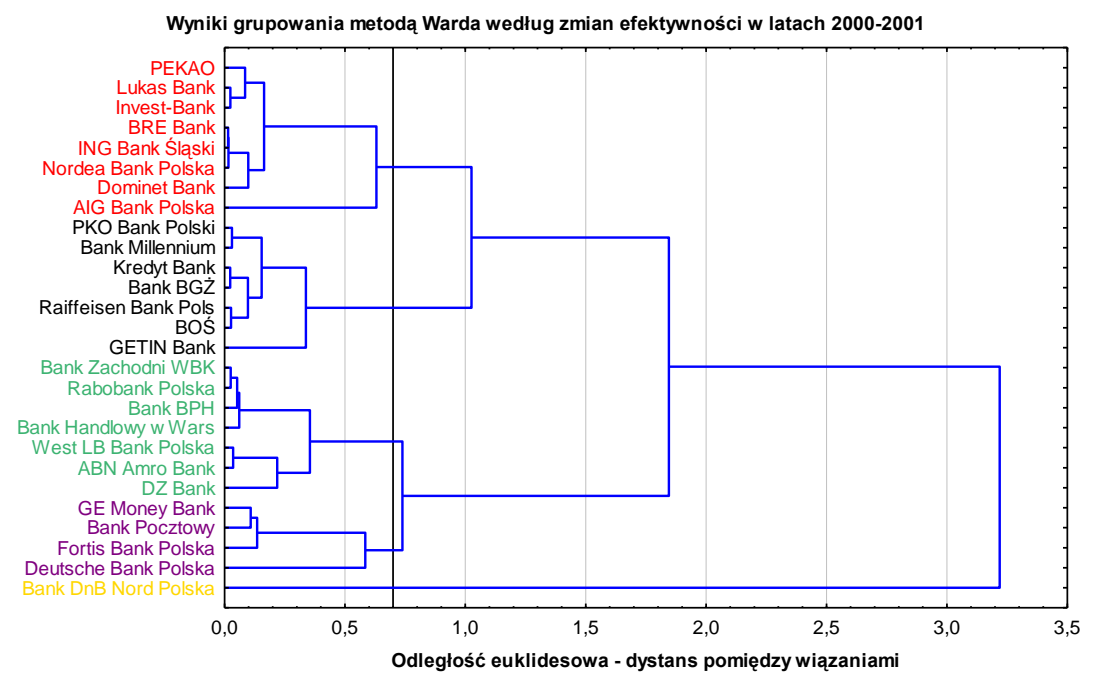

Źródło: opracowanie własne.

Grupa C składa się z siedmiu banków, wśród których znalazły się banki uniwersalne oraz cztery banki korporacyjne. Zarówno komponenty indeksu Malmquista, jak i jego poziom wykazywały tendencję wzrostową. Średni poziom wskaźnika zmiany efektywności technicznej wyniósł 17,7\%, wskaźnika zmiany technologii 9,7\%, indeksu Malmquista $15,7 \%$. Poziom minimum i maksimum statystyk opisowych dla tej grupy wskazuje, że wszystkie banki odnotowały wzrost jednostkowych wskaźników w latach 2001-2002. 
Tabela 3. Wybrane statystyki opisowe wskaźników w powstałych klastrach bankowych w latach 2001-2002

\begin{tabular}{|c|c|c|c|c|c|c|c|c|c|}
\hline \multirow{2}{*}{ Grupa } & \multicolumn{3}{|c|}{ EFF CH } & \multicolumn{3}{c|}{ TECH CH } & \multicolumn{3}{c|}{ TFP CH } \\
\cline { 2 - 11 } & średnia & min. & maks. & średnia & min. & maks. & średnia & min. & maks. \\
\hline A & 0,994 & 0,943 & 1,016 & 1,029 & 0,786 & 1,122 & 1,023 & 0,786 & 1,122 \\
\hline B & 0,987 & 0,878 & 1,020 & 1,245 & 1,160 & 1,385 & 1,226 & 1,180 & 1,296 \\
\hline C & 1,177 & 1,078 & 1,307 & 1,097 & 1,013 & 1,199 & 1,294 & 1,157 & 1,568 \\
\hline D & 0,839 & 0,717 & 0,881 & 1,180 & 1,145 & 1,227 & 0,990 & 0,845 & 1,054 \\
\hline E & 1,345 & 1,345 & 1,345 & 1,977 & 1,977 & 1,977 & 2,659 & 2,659 & 2,659 \\
\hline Ogół & 0,992 & 0,717 & 1,345 & 1,169 & 0,786 & 1,977 & 1,168 & 0,786 & 2,659 \\
\hline
\end{tabular}

EFF CH - zmiana efektywności, TECH CH - zmiana poziomu możliwości technologicznych,

TFP CH - całkowita zmiana produktywności

Źródło: opracowanie własne.

Grupę D utworzyły cztery banki, które zanotowały niewielki średni spadek poziomu produktywności całkowitej (TFP CH 0,99). Pozytywne zmiany w zakresie technologii (TECH CH 1,18) nie zrekompensowały regresu drugiej składowej wskaźnika Malmquista (EFF CH), który dotyczy zmiany efektywności technicznej. Pod tym względem banki z grupy D zanotowały średnio kilkunastoprocentowy spadek.

Jednoelementowe skupienie oznaczone jako grupa E tworzy DnB Nord, który charakteryzował się ponad dwukrotnym wzrostem poziomu produktywności całkowitej. Wynikało to zarówno z korzystnych zmian w zakresie efektywności technicznej, jak i postępu technicznego.

Rys. 4. Graficzna prezentacja poziomu wskaźników w powstałych klastrach bankowych w latach 2000-2001

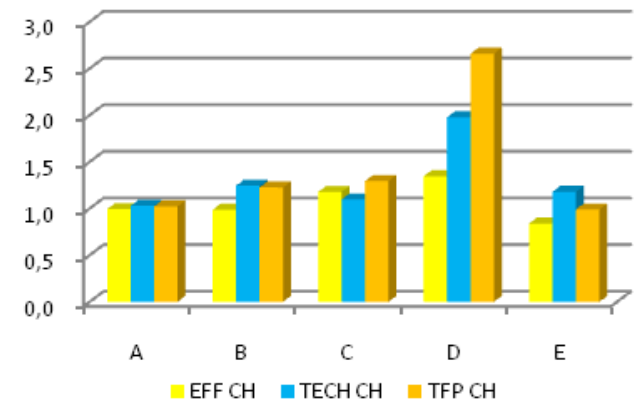

EFF CH - zmiana efektywności, TECH CH - zmiana poziomu możliwości technologicznych,

TFP CH - całkowita zmiana produktywności

Źródło: opracowanie własne.

Pod względem zmian poziomu produktywności całkowitej oraz czynników, które na nią wpływają w okresie 2006-2007 r., w badanej populacji banków wyróżniono trzy klastry bankowe. Ich skład, podstawowe statystyki opisowe oraz graficzną prezentację poziomu wskaźników w powstałych klastrach przedstawiono odpowiednio na rysunku 5, w tabeli 4 i na rysunku 6. 
Rys. 5. Klastry bankowe w latach 2006-2007.

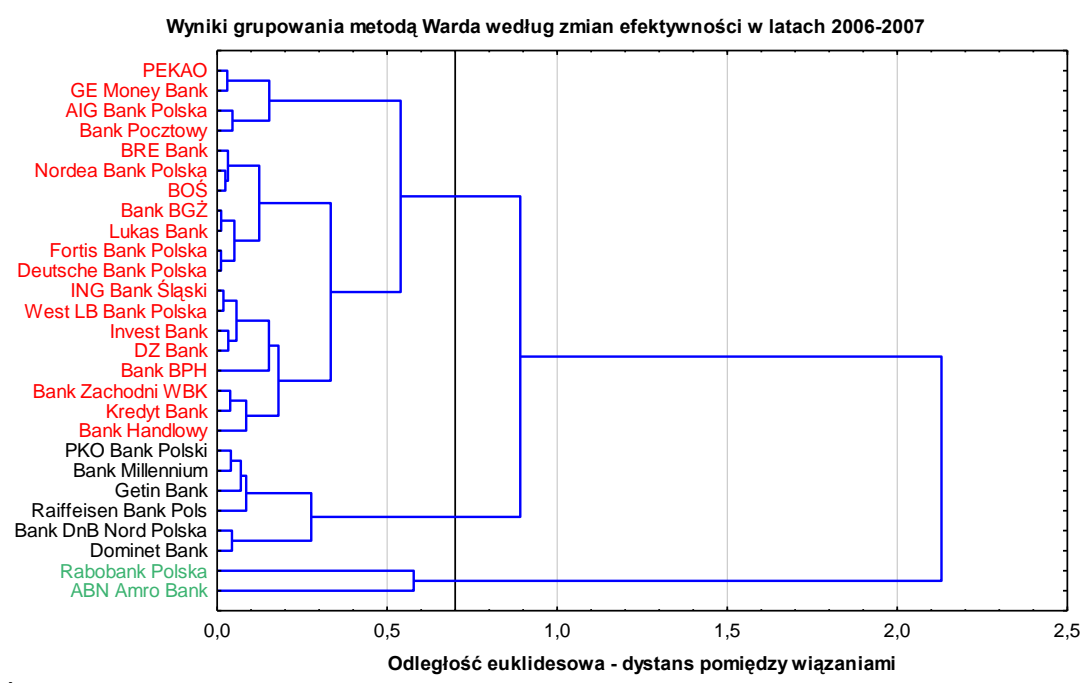

Źródło: opracowanie własne.

Do grupy A zaklasyfikowano większość z analizowanych banków. Z tego powodu pod względem rozmiarów oraz profilu prowadzonej działalności tworzą one bardzo zróżnicowany zbiór. Jednak wykazują podobieństwa w zakresie kształtowania się poziomu produktywności całkowitej. W grupie tej nastąpił bardzo niewielki średni spadek efektywności technicznej. Skala największego wzrostu efektywności technicznej wyniosła 6,5\%. Podobne tendencje dotyczyły poziomu wskaźnika zmiany technologii. W średnim ujęciu nastapił niewielki spadek, ale maksymalny wzrost tej kategorii w badanej grupie wyniósł 10,1\%. Tym samym produktywność obniżyła się średnio o $1 \%$.

Tabela 4. Wybrane statystyki opisowe wskaźników w powstałych klastrach bankowych w latach 2006-2007

\begin{tabular}{|c|c|c|c|c|c|c|c|c|c|}
\hline \multirow{2}{*}{ Grupa } & \multicolumn{3}{|c|}{ EFF CH } & \multicolumn{3}{c|}{ TECH CH } & \multicolumn{3}{c|}{ TFP CH } \\
\cline { 2 - 11 } & średnia & min. & maks. & średnia & min. & maks. & średnia & min. & maks. \\
\hline A & 0,998 & 0,914 & 1,065 & 0,992 & 0,861 & 1,101 & 0,990 & 0,861 & 1,101 \\
\hline B & 1,120 & 1,056 & 1,188 & 0,996 & 0,948 & 1,028 & 1,117 & 1,059 & 1,191 \\
\hline C & 1,000 & 1,000 & 1,000 & 1,559 & 1,354 & 1,763 & 1,559 & 1,354 & 1,763 \\
\hline Ogół & 1,026 & 0,914 & 1,188 & 1,035 & 0,861 & 1,763 & 1,060 & 0,861 & 1,763 \\
\hline
\end{tabular}

EFF CH - zmiana efektywności, TECH CH - zmiana poziomu możliwości technologicznych,

TFP CH - całkowita zmiana produktywności

Źródło: opracowanie własne.

Grupa B składa się z sześciu banków, wśród których znalazły się banki uniwersalne i detaliczne. Ich średnia produktywność wzrosła o ponad 11\%. Wszystkie banki z tej grupy odnotowały wzrost produktywności całkowitej mierzonej indeksem Malmquista. 
Zadecydowały o tym korzystne zmiany w obszarze efektywności technicznej, które wystapiły w tym czasie we wszystkich bankach z tej grupy (EFF CH).

Rys. 6. Graficzna prezentacja poziomu wskaźników w powstałych klastrach bankowych w latach 2006-2007

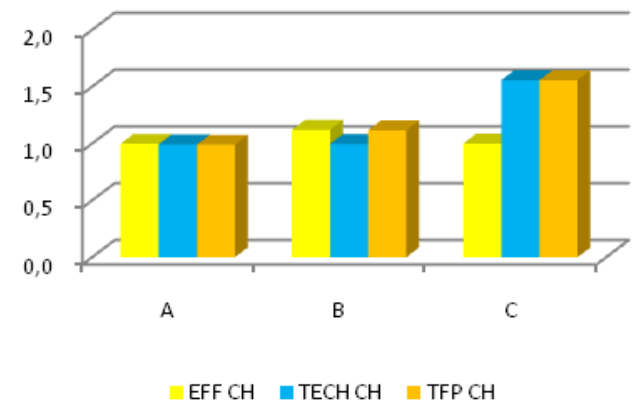

EFF CH - zmiana efektywności, TECH CH - zmiana poziomu możliwości technologicznych,

TFP CH - całkowita zmiana produktywności Źródło: opracowanie własne.

Grupę C tworzą dwa banki korporacyjne, które odnotowały bardzo korzystne zmiany w zakresie technologii. Ich średni wskaźnik postępu technologicznego wyniósł 55,9\%. Ponieważ efektywność techniczna się nie zmieniła, w tym samym stopniu poprawiła się produktywność całkowita.

\section{ZESTAWIENIE WYNIKÓW GRUPOWANIA}

Przeprowadzona procedura taksonomiczna umożliwiła zestawienie zmian w składzie poszczególnych skupień banków, które przedstawiono w tabeli 5.

Tabela 5. Zbiorcze zestawienie grupowania 27 banków ze względu na przyjęte zmienne diagnostyczne w badanych okresach

\begin{tabular}{|c|c|c|c|c|c|}
\hline $\begin{array}{c}\text { Klastry } \\
\text { bankowe w latach } \\
1996-1997\end{array}$ & & $\begin{array}{c}\text { Klastry } \\
\text { bankowe w latach } \\
2001-2002\end{array}$ & & $\begin{array}{c}\text { Klastry } \\
\text { bankowe w latach } \\
2006-2007\end{array}$ & \\
\hline PEKAO & & PEKAO & & PEKAO & \\
\hline Fortis Bank & & Lukas Bank & & GE Money Bank & \\
\hline Invest-Bank & & Invest-Bank & & AIG Bank Polska, & \\
\hline Kredyt Bank & & BRE & & Bank Pocztowy & \\
\hline GE Money Bank & & ING Bank Śląski & & BRE & \\
\hline AIG Bank Polska & & Nordea Bank & & Nordea & \\
\hline Bank BPH & & Dominet Bank & & Boś & \\
\hline Bank Zachodni WBK & $A$ & AIG Bank Polska & $A$ & BGŻ & $A$ \\
\hline Bank Pocztowy & & & & Lukas Bank & \\
\hline BRE & & & & Fortis Bank & \\
\hline ING Bank Śląski & & & & Deutsche Bank & \\
\hline Millennium & & & & ING Bank Śląski & \\
\hline Nordea Bank & & & & West Lb & \\
\hline West LB & & & & Invest Bank & \\
\hline BGZ̈ & & & & DZ Bank & \\
\hline
\end{tabular}




\begin{tabular}{|c|c|c|c|c|c|}
\hline DnB Nord & & & & $\begin{array}{l}\text { Bank BPH } \\
\text { BZ WBK } \\
\text { Kredyt Bank } \\
\text { Bank Handlowy }\end{array}$ & \\
\hline $\begin{array}{l}\text { Bank Handlowy } \\
\text { DZ Bank } \\
\text { Lukas Bank } \\
\text { GETIN Bank } \\
\text { Dominet Bank } \\
\text { Deutsche Bank }\end{array}$ & $B$ & $\begin{array}{l}\text { PKO BP } \\
\text { Kredyt Bank } \\
\text { Millennium } \\
\text { Raiffeisen Bank } \\
\text { BGŻ } \\
\text { BOŚ } \\
\text { GETIN Bank }\end{array}$ & $B$ & $\begin{array}{l}\text { PKO BP } \\
\text { Millennium } \\
\text { GETIN Bank } \\
\text { Raiffeisen Bank } \\
\text { DnB Nord } \\
\text { Dominet Bank }\end{array}$ & $\boldsymbol{B}$ \\
\hline PKO BP & $C$ & DnB Nord & $\boldsymbol{E}$ & $\begin{array}{l}\text { Rabobank } \\
\text { ABN Amro }\end{array}$ & $C$ \\
\hline \multirow[t]{2}{*}{$\begin{array}{l}\text { BOŚ } \\
\text { ABN Amro } \\
\text { Raiffeisen Bank } \\
\text { Rabobank }\end{array}$} & $D$ & $\begin{array}{l}\text { Bank Zachodni WBK } \\
\text { Rabobank } \\
\text { Bank BPH } \\
\text { Bank Handlowy } \\
\text { West LB } \\
\text { ABN Amro } \\
\text { DZ Bank }\end{array}$ & $C$ & & \\
\hline & & $\begin{array}{l}\text { GE Money Bank } \\
\text { Deutsche Bank } \\
\text { Bank Pocztowy } \\
\text { Fortis Bank }\end{array}$ & $D$ & & \\
\hline
\end{tabular}

Źródło: opracowanie własne.

Można zauważyć, że w latach 2001-2002 liczba wyodrębnionych klastrów zwiększyła się z czterech do pięciu. Świadczy to o zróżnicowaniu badanej populacji banków pod względem zmian w poziomie produktywności całkowitej. W ostatnim okresie analizowane banki utworzyły trzy skupienia. W tabeli 5 odrębnymi kolorami zaznaczono te banki, które zawsze występowały razem $\mathrm{w}$ skupieniu lub jeśli zostały zaklasyfikowane w kolejnym okresie do innego skupienia, to także razem przechodziły do innej grupy. Na przykład dwa banki oznaczone kolorem niebieskim w pierwszym okresie analizy zostały zaklasyfikowane do grupy B, w środkowym - do C, w ostatnim zaś - do A. Oznacza to, że zmiany produktywności całkowitej przebiegały $\mathrm{w}$ nich na tyle podobnie, że w każdym $\mathrm{z}$ okresów objętych analizą znajdowały się w tym samym skupieniu.

\section{PODSUMOWANIE}

W artykule przeprowadzono grupowanie 27 banków w Polsce pod względem wskaźnika produktywności całkowitej oraz jego elementów składowych w latach 1996-1997, 2001-2002 oraz 2006-2007. Zastosowano nieparametryczną metodę DEA, indeks produktywności Malmquista oraz procedurę taksonomiczną. Pozwoliło to na wyodrębnienie skupień analizowanych banków w badanych okresach. Mimo wyraźnych różnic dotyczących wielkości, struktury właścicielskiej i typu właściciela oraz profilu specjalizacyjnego, analizowane banki wykazywały podobieństwa pod względem poziomu wskaźników w obrębie grup. Na przykład w okresie 1996-1997 r. najliczniejszą i zarazem najbardziej zróżnicowaną grupą banków jest grupa A, w której znalazły się zarówno banki uniwersalne, detaliczne, jak i 
korporacyjne. Mimo różnic pod względem zmian poziomu produktywności całkowitej wykazują one podobieństwa.

Jednym z rezultatów analizy jest także prześledzenie fluktuacji banków pomiędzy grupami w poszczególnych okresach. Na tej postawie zaobserwowano pewną prawidłowość, którą można prześledzić także na przykładzie banków z grupy A. Sześć z nich (oznaczonych w tab. 5 kolorem czerwonym) w latach 1996-1997, 2001-2002 i 2006-2007 zaklasyfikowano do tego samego skupienia. W tym wypadku była to zawsze grupa A. Wskazuje to na podobieństwa $\mathrm{w}$ poziomie produktywności tych banków. Banki oznaczone innymi kolorami razem zmieniały swoje położenie w ramach wyodrębnionych skupień. Wynika z tego, że wykazywały podobieństwa $\mathrm{w}$ tendencjach zmiany poziomu produktywności całkowitej.

Wydaje się, że przeprowadzona analiza może stanowić przyczynek do dalszych badań z wykorzystaniem zaproponowanej metodyki. Intencją autorów jest poszerzenie prowadzonej analizy o ranking badanych banków, który pozwoli na identyfikację obiektów o najwyższych poziomach zmiennych.

\section{LITERATURA}

[1] Berger A.N., Humprey D.N., Efficiency of Financial Institutions: International Survey and Directions for Future Research, [w:] Performance of Financial Institution, [red. P. Harker, S. Zenios, Cambridge University Press, New York 1999], Oxford University Press, Oxford 1999.

[2] Charnes A., Cooper W.W., Rhoades A., Measuring the efficiency of decision making units, „European Journal of Operational Research” 1978/2.

[3] Favero C.A., Papi L., Technical Efficiency and Scale Efficiency in the Italian Banking Sector: Non-parametric Approach, „Applied Economics” 1995/27.

[4] Freixas X., Rochet J.Ch., Mikroekonomia bankowa, CeDeWu, Warszawa 2007.

[5] Gospodarowicz M., Procedury analizy i oceny banków, „Materiały i Studia”, NBP, Warszawa 2005/103.

[6] Grabiński T., Metody Taksonometrii, Akademia Ekonomiczna w Krakowie, Kraków 1992.

[7] Marek T., „Analiza skupień w badaniach empirycznych: metody SAHN, PWN, Warszawa 1989.

[8] Ostasiewicz W., Statystyczne metody analizy danych, Wydawnictwo AE, Wrocław 1998.

[9] Ward J.H., Hierarchical Grouping to Optimize an Objective Function, „Journal of the American Statistical Association" 1963/58.

[10] Wheelock D.C., Wilson P.W., Evaluating the efficiency of commercial banks: does our view of what banks do matter?, „Review of Federal Reserve Bank of St. Louis” $1995 / 77$ 
PRODUCTIVITY EVALUATION OF BANKS IN POLAND - TAXONOMIC ANALYSIS

The main aim of this study is an evaluation of total productivity changes of banks in Poland according to a selected set of diagnostic variables (efficiency change, technical change, total factor productivity change). The DEA method, Malmquist index, cluster analysis - Ward method and the method of group average were applied. Based on the taxonomical procedure the banks clusters of similar level of chosen variables were created. Keywords: productivity, DEA, Polish banks.

DOI:10.7862/rz.2012.einh.3 